\title{
Akis Dergisi “Kadınlar Arasında” Bölümünde Kadın Algısı
}

\author{
Öğr. Gör. Seyran Efilti Atay \\ Akdeniz Üniversitesi, Manavgat MYO \\ Çocuk Gelişimi Pr. \\ efilti@akdeniz.edu.tr
}

\author{
Öğr. Gör. Dr. Hilal Karavar \\ Akdeniz Üniversitesi, Ĕ̆itim Fakültesi \\ Sosyal Biligiler Öğretmenliği Pr. \\ hilalkaravar@hotmail.com
}

Öz

Kadın dergilerinde ya da dergilerin kadına yönelik bölümlerinde üretici konumundan çıartılan kadınlar, toplumsal önyargılarla inşa edilmiş bir yaşam biçimi içinde tasvir edilmiştir. Kadına yönelik dergilerde kadın, toplumsal sorunlar, adalet, eşitlik, yoksulluk gibi kavramlar karşısındaki konumu ile değil; aşk, para, güzellik gibi kavramlarla sembolize edilen bir konuma indirgenmiştir. 1954-1967 arasında yayımlanan Akis dergisi bir kadın dergisi olmamakla birlikte "Kadınlar Arasında" bölümüyle dönemin kadın kimliğine yönelik eleştirel bir bakış açısına sahip olması onu diğer dergilerden ayırmaktadır. $\mathrm{Bu}$ çalışmada Akis dergisinin kadının toplumsal hayattaki yeri üzerine olan düşünsel perspektifi analiz edilmeye çalışılmıştır. Bu amaçla 15 Mayıs-25 Aralık 1954 yılları arasındaki 33 sayı niteliksel içerik analizi yöntemiyle incelenmiştir. Derginin "Kadınlar Arasında" bölümü köşe yazıları ve haber metinleri olmak üzere iki kategoride değerlendirilmiştir. Araştırma sonucunda köşe yazılarında Türk kadının toplumsal, ekonomik ve siyasal yaşamda etkin bir kimliğe sahip olması gerekliliği üzerinde durulmuştur. Özellikle ekonomik ve siyasal anlamda Amerikan kadınının rol model olarak sunulduğu görülmektedir. Haber metinlerindeyse kadının geleneksel rolleri, günlük yaşam pratikleri içerisinde değerlendirilmiştir. Sonuç olarak Akis dergisinde kadın algısı geleneksel, popüler yaşam ve Cumhuriyetin kadına veridiği haklar ekseninde şekillendiği görülmektedir.

Anahtar Kelimeler: Akis, kadın, siyaset, niteliksel içerik analizi.

\section{The Perception of Women in the "Among Women" Section of Akis Magazine}

\footnotetext{
Abstract

In women's magazines or in the women's sections of magazines, women are depicted in a lifestyle built by social prejudices. In women-oriented magazines, women do not stand against concepts such as social problems, justice, equality, and poverty; woman is reduced to a position symbolized by concepts such as love, money, beauty. Although Akis magazine, published between 1957 and 1967, is not a women's magazine, it has a critical perspective on the female identity of the period with its section Among Women, which distinguishes it from other magazines. For this purpose, 33 issues between 15 May and 25 December 1954 were analyzed by qualitative content analysis method. The "Among Women" section of the magazine has been evaluated in two categories: columns and news articles. As a result of the 
research, the necessity of Turkish women to have an active identity in social, economic and political life was emphasized in the columns. It is seen that American women are presented as role models, especially in economic and political terms. In the news texts, the traditional roles of women are evaluated within their daily life practices. As a result, it is seen in Akis magazine that the perception of women is shaped around the traditional, popular life and the rights granted to women by the Republic.

Keywords: Akis, women, politics, qualitative content analysis. 


\section{GİRIŞ}

Bir toplumda kadınların farkındalık yaratmak ve bu süreçte örgütlü mücadeleye girebilmesi için üç aşamanın varlığı gereklidir. Birinci aşamada her alanda değişim geçiren toplumda önce değişim sonrasında yaşanan kaosun bitmeli ve özgür bir ortam oluşmalıdır. İkinci aşamada kadının yasalarla oluşturulmuş eşitlik ve özgürlük kavramının kendisini kapsamadığını farketmesi gerekir. Üçüncü aşamada artık kadınlar, kadınlık bilincine ulaştıktan sonra kendi sorunlarını kendi çözebilecekleri sonucuna vararak özgürlük, hak ve eşitlik için örgütlü mücadeleye girerler (Çakır, 1996, s. 315). Bunun gerçekleşebilmesi için kitle iletişim araçlarının etkin olarak kullanılması zorunludur. Doğal olarak bu durum kitle iletişim araçlarını önemli kılmaktadır.

Dergilerde inşa edilen kadınlık algısı ülkenin tarihsel süreç içerisindeki ekonomik, toplumsal ve kültürel yapısında yaşanan dönüşümden etkilenmiştir. Türk gelenek yapısı içerisinde kadının konumunu incelediğimizde özellikle İslamiyet öncesi göçebe toplumlarda kadın tıpkı erkekler gibi toplumsal, dini, siyasi ve hukuk bakımından güçlü bir konumda bulunmaktadır. Eski Türk toplumunda ailenin servetinde ortaklık mevcuttur. Kadın eşi öldüğünde serveti yönetir, miras ve boşanma hukuku konusunda eşitlik söz konusudur. Siyasal alanda yer edinen kadın devlet yönetiminde görev alabilmektedir (Tekelioğlu, 2016, s. 214). Bu konum sayesinde kadının kamusal ve özel alanda görünürlügü artmıştır. Ataerkil toplumlarda olduğu gibi sadece iyi bir eş, iyi bir anne ve iyi bir ev hanımı rolü ile pasif bir konuma itilen kadın; Türk toplumunda ata binen, ok atan gerektiğinde eşi ile birlikte savaşa katılabilecek güçlü bir kadına dönüşmüştür.

Osmanlı döneminde kadın genel olarak kent yaşamında görünür bir kimliğe sahip olmadığı gibi devletin teokratik yapısı da kadını eve ve erkeğe bağımlı hale getirmiş; toplumsal yaşamda ikincil bir konuma yerleştirmiştir. Ancak II. Meşrutiyet'in (1908) ilanından sonra Osmanlı'da özellikle eğitim ve hukuk alanında yaşanan değişim kadın ve kadın algısının sorgulanmasını da beraberinde getirmiştir. Türk kadınları II. Meşrutiyet sonrası dönemde örgütlü mücadelelerini kurdukları dernek ve yayımladıkları dergi ve gazetelerle desteklemişlerdir. Bu dönemde hazırlanan dergi ve gazetelerde geleneksel ve dini kalıplar içerisine sıkışmış kadınların batıdaki gibi toplumsal alanda yaşanan mücadelelerden yola çıkarak kadının her alanda eğitilmesi ve bilinçlenmesi esas alınmıştır. $\mathrm{Bu}$ dönemde yayımlanan dergilerin en başında Kadın, Mehasin, Kadın Bahçesi, Kadınlar Dünyası, Kadın Hayatı, Kadınlar Duygusu, Kadın Kalbi gibi yayınlar gelmektedir (Aydın, 2015, s. 87). Ancak bu dönemde yayımlanan dergilerdeki iki temel sorun göze çarpmaktadır. Birincisi dergilerin kapsamının kır hayatında yaşayan kadınlardan öte büyük kentte yaşayan kadınlara hatta sınırlı sayıdaki kadınlara yönelik olmasıdır. İkincisi dergiler aracılığıyla kadınların anayasal beklentilerinin artmasına paralel olarak dönemin koşulları çerçevesinde devletin kadınlara ancak sınırlı hak ve özgürlükleri verebilmesidir.

Cumhuriyetin ilanı sonrasında, 1923-1930 yıllarındaki inkılap hareketleriyle Türkiye'deki kadının statüsünde değişmeler yaşanmıştır. 1924 yılında yürürlüğe konan Tevhid-i Tedrisat Kanunu ile eğitim devletin kontrolünde merkezileşmiş, bilimsel yönetim esaslarına dayanarak kadınların da eğitimdeki ayrıcalıklardan yararlanması sağlanmıştır. Hukuki bakımdan 1926 yılında kabul edilen Medeni Kanun'la kadın-erkek eşitliği kabul edilmiş; kadına istediği mesleği seçebilmesi hakkı tanınmıştır. Siyasal alanda kadınlara, 1930 'da belediye seçimlerine katılma hakkı, 1933'te muhtar seçme hakkı ve 1934'te ise milletvekili seçme ve seçilme hakları tanınmıştır (Gökçimen, 2008, s.22). Ancak tüm bunlara 
rağmen kadının toplumsal konumunun istenilen ve cumhuriyetin ilk yıllarında hedeflenen yere ulaştı̆̆ını söylemek zordur. Örneğin Şirin Tekeli (2017), "10 madde de kadın hareketi" yazısında özellikle 1935-1975 yılları arasındaki dönemi kadının kimliğine yönelik mücadelelerin ortadan kalktığ edinme olanaklarından seçkin bir azınlığın yararlandığı, bu ayrıcalıklara sahip olmayan ve toplumun büyük bir çoğunluğunu temsil eden kadınların ise ataerkil gelenekleri kıramaması sonucu tarım kesiminde ücretsiz aile işçisi olarak çalıştırıldığı, mülkiyet, eğitim, gelir, sosyal güvenlik haklarından yoksun kaldıklarına çalışmasında yer vermiştir. Çünkü Cumhuriyet dönemi ile birlikte çeşitli kazanımlara sahip olan kadın, Osmanlı dönemindeki kadın gibi hak arayış, kadın-erkek fırsat eşitliği mücadelelerinden uzaklaşarak fiziksel görünümü ile bir kimlik yaratma sürecine girmiştir. Bu süreç kadın dergilerinde de yansımalarını göstermiş, dergi yayın politikalarında, dergi içeriklerinde ve tasarımlarında dönemin yaşam şeklinin etkisi olduğu görülmüştür (Malkoç ve Yılmaz, 2019, s. 2141).

Türkiye'de yapılan akademik çalışmalarda, Osmanlı'dan itibaren yayaımlanan kadın dergileriyle ilgili çeşitli incelemeler yapılmıştır. Örneğin Neslihan Kılıç'ın (2015, s. 744-769), Tanzimat sonrasında yayım hayatına başlayan ilk kadın dergisi Mürüvvet'i incelediği “Osmanlı Kadın Dergilerine Bir Örnek: Mürüvvet" adlı çalışmasında sosyal hayatta sesini duyuramayan Osmanlı kadını basın aracılığıyla bu imkânı bulduğunu ifade etmiştir. Muhafazakâr çizgide yayın politikasına sahip olan dergi, toplumsal ahlaki konulardan ve günlük hayatta kullanılabilecek pratik bilgilerden bahsetmiştir. Osmanlı kadınının sergilemesi gereken davranışlar üzerine kurulu olan dergi, giyim kuşam konusunda Avrupalı kadınları eleştirmiştir. Tülay Kesgin'in (2005, s. 289-312), II. Meşrutiyet Dönemi sonrasında 1908 yılında yayınlanan Demet dergisinde "Kadın ve İlerleme Anlayışı" çalışmasında; dergide yer alan yazılarda kadının geri kalmışlığı ile toplumun geri kalmışlığı özdeş tutulmuş, bu nedenle ulusun ilerlemesi için kadınların eğitim alması gerekliği ifade edilmiştir. Ancak söz konusu dergide eğitim kadının kişisel gelişimine katkıdan öte 'gelecek yetiştiricisi ve ulusun annesi' rolü nedeniyle önemli atfedilmiştir. Demet dergisinde kadın eğitimi konusunun yanında çocuk bakımı, kadın terbiyesi, güzellik, yüz bakımı ve moda gibi gündelik yaşam pratiklerine de yer verilmiştir. Hakan Aydın'ın (2009, s. 147-156), "Kadın (1908-1909): Selanik'te Yayınlanan İlk Kadın Dergisi Üzerine Bir İnceleme" adlı çalışmasında incelediği dergide kadınların eğitimi, toplumsal yaşama katılması, örgütlenmesi önem verilen konular arasındadır. Derginin ilk sayısında tüm kadınlara yönelik hazırlandığı ifade edilse de içerikte kullanılan dilin ağır ve ağdalı yapısı eğitim dışında kalan kadınlara hitap edilemediğini göstermiştir. Kadınların eğitilmesi toplumsal yaşama katılmaları, bu yönde deneyimler elde edecekleri örgütlü birliktelikler oluşturmaları önemlidir. Ancak kadının eğitilmesi ev idaresi ve çocuk bakımı gibi konular çerçevesinde ele alınmıştır. Dergide ideal olarak tasvir edilen kadın, sağlam bir nesil, cesur asker yetiştiren bilgili bir anne ve ev işlerini bilinçli şekilde yapan ev kadınıdır. Besim Yıldırım ve Salih Seyhan'ın (2015, 39-65), “1914 Yılında Yayınlanan Kadın Gazetelerinden 'Kadınlık'a Göre Kadın" çalışmasında incelenen gazete yazılarında toplumsal değişimde kadının modernleşmesi gerekliliği üzerinde durulmuş ancak bu modernleşme süreci ataerkil yapı çerçevesinde sınırlandırılmış, kadının kimliği ve algısı ev ve aile kapsamında ele alınmıştır. K1lıç ve Yilmaz'ın (2019, s. 2139-2156), “Cumhuriyet Dönemi Kadın Dergileri (1923-1992)" başlıklı araştırmasında belirli dönemlerde yayınlanan 12 kadın dergisinde kadınların toplumsal ve özel alanda kendi algılayış biçimlerine hangi perspektiften baktıkları incelenmiştir. İnceleme sonucunda Cumhuriyet dönemindeki kadın dergileri içinde kadın, 
Osmanlı dönemindeki kimlik mücadelelerinde ayrışan, sadece belirli haklar elde etmek isteyen, fiziksel görünümü ile kendini ispatlama çabası içinde olan kadına dönüşmüştür. Dergilerde siyasal, toplumsal gerçekler dışında moda, güzellik, kadın cinselliği, sağlık, eğlence, astroloji, magazin, yemek, kadın erkek eşitliği gibi konulara vurgu yapılmıştır. Dilara Koçer (2009, s. 131-143), “Demokrat Parti Dönemi (1950-1960) Kadın Dergilerinde Kadın İmajı" çalışmasında Demokrat Parti döneminde yayımlanan 17 dergiyi incelemiştir. Araştırma sonucuna göre dergilerde kadının geleneksel rolleri ataerkil yapı içinde yeniden tanımlanmıştır. Kadın için en iyi iş olarak ev kadınlığı tavsiye edilmiş, kadın eş olarak, erkeğin hizmetinde, erkeğe tabi, muhtaç, pasif ve itaatkâr olarak resmedilmiştir. Dergilerdeki ideolojik alandaki boşluk, aşk hikâyeleri, magazin dedikoduları ve erkek tavlama yöntemleriyle doldurulmaya çalışılmıştır. Yine adı geçen çalışmada mutluluğun kaynağı olarak evlilik ve paranın baz alındığı, kadınlara dergiler yoluyla çalışmak yerine zengin biriyle evlenmesinin tavsiye edildiği görülmüştür

Kadınların siyasal ve toplumsal alanda yaşanan değişimler konusunda ilgisiz ve tepkisiz kalması dönemin kadın dergilerinde ele alınan konuların işleyiş biçimini de etkilemiştir. Cumhuriyet dönemi kadın dergilerinde temel hedef Cumhuriyet Kadın nitelemesine uygun bir kimlik yaratmaktır ve maalesef ki bu dış görünüş olarak kalmıştır (Mutlu, 2009, s. 61). Verilen çalışma örneklerinden de anlaşılacağ gibi akademik alanyazında dönemler itibariye kadına yönelik dergilerde yapılan çalışmalarda benzer söylemlerle kadınlık algısının inşa edildiği görülmektedir.

Bu çalışmayı diğer çalışmalardan farklı kılan yanı Akis dergisinin bir kadın dergisi olmamasıdır. Dönemin siyasal dergicilik anlayışında önemli bir yer tutan Akis'in, kadına yönelik hazırlanan bölümünde kadının kamusal alan içerinde yer alması konusu köşe yazılarında ve haber metinlerinde yer vermiştir. Bazı sayılarında Türkiye'de ve dünyada örnek gösterilen, kendi alanlarında üretken kadınların fotoğrafları dergi kapağında kullanmıştır.

$\mathrm{Bu}$ araştırma monografi özellliği taşımakla birlikte çalışmada niteliksel içerik analizi yönteminden yararlanılmıştır. 1954-1967 yılları arasında yayımlanan Akis dergisinin 33 nüshası araştırma kapsamı içine alınmıştır. Dergideki "Kadınlar Arasında" bölümü iki kategori halinde incelenmiştir. Birinci kategoride kadına yönelik hazırlanan köşe yazılarının; kadın-siyaset, kadın-toplumsal konum, kadın-eğitim, kadın-hak arayışları içerisinde konumlandırılış biçimi dikkate alınmıştır. İkinci kategoride ise kadına yönelik haber metinlerinde kadının geleneksel rolü gündelik yaşam pratikleri açısından incelenmiştir. Araştırma kapsamında bulunan dergi nüshalarında kadına yönelik köşe yazıları ve haber metinleri birbirlerinin tekrarı niteliğinde olduğu için çalışma farklı konulara değinen dergi sayıları ile sınırlanmıştır. Bu doğrultuda kadına yönelik hazırlanan 15 Mayıs-11 Eylül 1954 arasındaki nüshalarda yeralan 10 köşe yazısı ve 15 Mayıs-25 Aralık 1954 arasındaki nüshalarda yeralan 15 güncel yazı/haberler ele alınmıştır. Çalışmanın amacı siyasi kimliğe sahip olan haftalık bir derginin kadına bakış açısını ve konumlandırılışını belirlemektir.

\section{Akis Dergisinin Kimlik Bilgileri ve Yayın İlkeleri}

Türkiye'de yayınlanan ilk haftalık dergi olarak nitelendirilen Akis, 15 Mayıs 1954 yılında Ankara' da yayın hayatına başlamıştır. İmtiyaz sahibi ve yazı işlerini fiilen idare eden Metin Toker'dir. Derginin kapağında "Haftalık Aktüalite Mecmuası" ibaresi vardır. 15 Mayıs 1954 tarihinde fiyatı 60 kuruştur. Derginin abonelik sistemi de bulunup 12 nüshası (3 aylık) 6 lira; 25 nüshası (6 aylık) 12 lira ve 52 nüshası (1 yıllık) 24 liradır. İncelenen dönem 
içerisinde derginin ücreti değişmemiştir. Dergi kapaklarında dönemin ünlü politik isimlerine yer verilmiştir. 15 Mayıs 1954'te "Milli Değer" olarak nitelendirdiği Leyla Gencer; 21 Ağustos 1954'te Belgin Doruk; 18 Eylül 1954'te "En Güzel Türk" nitelemesiyle Sibel Göksel; 16 Temmuz 1954'te Nur Sabuncuoğlu; 13 Kasım 1954'te Florence Nightingale kapak resmi olarak kullanılmıştır. Yayın politikası gereği dergi genel itibariyle hedef kitlesini belirli konularda bilgilendirmek, eğitmek ve okuyucuların zihninde yeni fikirlerin oluşmasında yol gösterici olmayı amaçlamıştır. Derginin hedef kitlesi "Siz biz İşte" olarak nitelendirdiği orta sınıf olarak tanımlanan olarak kitleler ve aydın kesimlerdir. Bu sebeple yayımlandığı dönemin iktisadi- politik gelişimlerine ışık tutan dergi, aynı zamanda askeri, tıp, kültür, sanat ve spor alanlarında Türkiye ve dünyada yer alan gelişmeleri okuyucunun anlayabileceği bir dilde ifade etmiştir.

Akis dergisi ilk sayısında yayımlanma amaçlarını şu şekilde açıklamaktadır: "Gayemiz nedir? Bir aktüalite mecmuası meydana getirmek. Bir aktüalite mecmuası ki onu okuyan münevver, kendisini alâkadar eden her mevzuu bulabilsin. Bir hafta içinde yurtta olup bitenleri toplu halde gözden geçirebilsin. Bizim "münevver" den anladı̆̆ımız, kuyusunun dibinde yaşayan âlim değildir. Çeşitli mevzularda derinliğinden ziyade genişliğine bir fikir sahibi bulunan, politikaya da merakl, maça da giden, iktisadî meseleleri de takip eden, sinemayı da seven, kitap okuyan, hâdiseleri bilen bir insan... Siz, biz İşte! Öğretmen, doktor, avukat, subay, üniversiteli, memur, asistan, profesör, ev kadını... Sayfaları açınız, iç politika da bulacaksınız, dış politika da iktisadî ve mali kısımlar da, tıp da, askerlik de, kadın sayfası da, spor da, sanat da, sinema da, kitaplar da... Ki bu, mevzularda en ciddi meseleleri en cazip tarzda kaleme alacak, hadiseleri gazetelerde okuduğunuz kuru şekillerinden kurtarmaya çalışacak, iç yüzleriyle ortaya koyacak, onları kendine has bir tarzda işleyecektir. Her bir sayfamız, o mevzuda en ziyade selahiyet sahibi bir arkadaş tarafindan hazırlanmaktadır" (Akis, 1954a, s. 3).

18 Eylül 1954 yılındaki sayısında; "Birçok dostumuz, hem de meslekten anlayan dostumuz, bizi ikaz etmeyi faydalı buldular. Dediler ki: «- Böyle bir mecmuanın tutmasın gönül çok ister. Ama, bu memlekette tutmaz. Okuyucu çıplak kadın resmi, hafif magazin yazlları arzu ediyor. Baksanıza, piyasadaki mecmualara... Bizim münevver, maalesef okumuyor.» İtiraf etmek gerektir ki, bu neviden ikazlara kulak vermemezlik etmedik, Gene itiraf etmek gerekir ki, haklar var gibi görünüyordu. Ama bizim, okuyucumuz diye seçtiğimiz zümreye itimadımız vardı. Biz kabahati o zümrede değil, o zümreyi tatmin edemeyen bizlerde görüyorduk. Cevabımı, daima şu oldu: «-Bunu neye dayanarak söylüyorsunuz? Sizin beğeneceğiniz bir mecmua çıktı da, siz onu okumamazlık mı ettiniz? Ve AKISS çıtı" ifadesiyle 'ciddi ama sıkmayan bir dergi' anlayışına sahip olduğunu dile getirmiştir (Akis, 1954b, s. 3).

Yayına başladığı ilk günden itibaren "tarafsız bir yayın politikası" uygulayacakları sözünü veren dergi, daha ilk sayısında çeşitli kesimler tarafından eleştiriye maruz kalmıştır. Bunlardan ilki, dergide Metin Toker'in Demokratik Parti döneminde uygulanan antidemokratik uygulamaları eleştirmesi ve bu yüzden derginin yapıcı olmaktan çok yıkıcı olduğuna dair iktidar ve iktidar yanlılarının söylemleridir. İkincisi ise Metin Toker'in İsmet İnönü'nün kızı ile evlenmesi sonrası Milli Damat olarak ilan edilmesidir. Ek olarak bir diğer eleştiri Devlet Bakanı Mükerrem Soral'ın istifasına yönelik kampanyaları yürütmesi; derginin Cumhuriyet Halk Partisi'nin bir yayın organı olduğu yönünde bir algı yaratmasıdır (Çelebi, 2017, s. 99).

Metin Toker, Akis'in ikinci sayısında yer alan "Kendi Aramızda" köşesinde derginin tarafsızlı̆̆ konusunda yapılan eleştirilere açıklık getirmiştir. $\mathrm{Bu}$ açılamada; 
“Okuyucularımı ekseriyet itibariyle dergimiz konusunda memnunlukların beyan ettiler. Ayn yolda devam edeceğiz. Aldığımız mektuplar arasında siyasî bakımdan tarafsızlığımızdan dolayı bizi alkışlayanlar, miktarı en yüksek olanlar; Buna mukabil, bazıları Demokrat Partiyi, bazıları Halk Partisini "tuttuğumuzu" ileri sürerek tenkidlerde bulunuyorlar Bunu da, tarafsızlğ̆ın icabı sayarak hoş karşıladık. Fakat inanılsın ki, ilk sayımızda ifade ettiğimiz' gibi, fikirleri, rengi ne olursa olsun memlekette bir kıymet ifade eden şahsiyetlerin en aktüel meseleler hakkındaki düşüncelerini sütunlarımızda bulmakta devam edeceksiniz. Fikirler onlarındı, biz aksettiriyoruz. Haftanın her sahadaki icmali de, aynı bitaraf gözle yapılmaktadır, yapılacaktır" ifadesine yer verilmiştir (Akis, 1954c, s. 3).

Akis'in 26 Haziran 1954 sayısında "Kendi Aramızda" köşesinde dergide yer alan içerikler ile birlikte bu içerikleri oluşturan yazarların da 'tarafsızlık ilkesi' gereği seçildiğini ifade edilmiştir. Söz konusu sayıda açıklama şöyledir: "AKIS'in bir hususiyeti vardır: Kendilerinden yazı istenilen muharrirler, mevzuları tayin edilse de, bu mevzuları işleyiş bakımından tamamiyle serbest bırakılırlar. Şimdiye kadar tek kimsenin makalesini "fikrinize iştirak etmiyoruz" diye reddetmedik. Yalniz, makale rica ederken, hep, kanaatleri - hangi taraftan olursa olsun - bir değer taşıyanları tercih ettik, basında isimleri pek fazla duyulmuş, her yere yazan, her "meokute" de yazısı bulunanlar istemedik. Makalelerin kenarındaki tefsirlerde ise - ki bunlar bir bakıma tefsirdir, bir bakıma haftanın hikâyesi - daima ortada kalmak, taraf tutmaksızın meseleleri gözden geçirmek prensibine sadik kaldik"(Akis, 1954d, s. 3).

1954 yılında yayın hayatına başlayan Times ve Newsweek gibi batılı dergileri örnek alan ve 1965 yılından itibaren politik imajından uzaklaşan Akis, yeni basım teknolojilerine ayak uyduramaması nedeniyle 31 Aralık 1967 ‘de yayın hayatından çekilmiştir (Özcan 1996, 158).

\section{Akis Dergisinde Kadın Sayfasında Yer Alan Köşe Yazılarının Analizi}

Derginin 1954 yılında yayımlanan ilk sayısında dönemin siyasal alanda yaşanan gelişmelere paralel söylemlerin olduğu görülmektedir. Bu dönemde öne çıkan gelişme 2 Mayıs 1954'te yapılan genel seçim ve bu seçim sonrası Türk siyasal alanda yaşanan değişimdir. Bilindiği üzere 1946' da Türkiye çok partili siyasi sisteme geçmiştir. Gerek 1946 gerek 1950 seçimlerinde CHP iktidar partisi; DP ise muhalefet partisi olarak seçimlere girmiştir. Bu anlamda 1954 seçimini özel kılan, önceki seçimdeki durumun tersinin yaşanmasıdır. Yani DP'nin iktidar partisi olarak CHP'nin ise muhalefet partisi olarak seçimlere katılmış olmasıdır. Böylece Türk seçmenler icraatlarını deneyimlediği iki parti arasında ilk kez seçim yapmıştır. 1954 seçimlerinin bir diğer önemli özelliğiyse iktidar ve muhalefetin kurumsallaşmasını sağlarken seçim boyunca iktidar ve muhalefetin uyguladığ 1 propaganda süreçlerinin sonraki dönemleri de etkilemiş olmasıdır (Yılmaz, 2010, s. 542).

Akis dergisi güncel siyasi olaylara duyarsız kalmamış, 1954 yılında yapılan seçim ve seçim sonrasındaki sürece "Kadınlar Arasında" bölümününde yer vermiştir. Ancak seçimlerin özelliklerinden çok siyasi hayatta Türk kadının konumu ile ilgili bir değerlendirme yapılmıştır. Şöyle ki Tülya Nemluk'un 15 Mayıs 1954'te çıkan "Türk Kadını ve Siyaset" başlıklı köşe yazısı, 14 Mayıs'ta yapılan yemin töreni ile başlamaktadır. Türk halkının \%90'a yakını seçimlere katılmıştır. Sadece erkekler değil kadınlar da seçimlere katılım göstermişlerdir. "...Gazetelerde hep okuduk, resimlerini gördük, şartları ne olursa olsun, yaşları ve sihhatleri müsait olsun olmasın, hiçbir Zahmet Türk kadınını haklarım kullanmaktan menedemedi; 90'lk bir nine, emzikli bir kadın, ayakta duramayacak kadar hasta bir kadın sandık başında saatlerce bekleşmekten çekinmemişlerdir..." cümleleriyle seçime olan ilgi ve katılımı ortaya koymuştur. Yazının devamında TBMM'de kadın milletvekili oranının \%1'den 
aşağıda olması eleştirilmiştir. Aslında kadının siyasetle iç içe olduğunu belirten yazar örnek olarak "..Çocuklarının tahsilini, sıhhatlerini düşünen bir anne, Türk maarifinin, sihhat teşkilâtımızın meselelerine karşı alâkasız olamaz. Evinin geçimini düşünen ev kadını, piyasa ve hayat pahalılı̆̆l, dolayısiyle iktisadi işlerimize karşı alâkasız olamaz; iş sahibi olup vergi ödeyen kadının bu paranın ne olduğunu merak etmesinden daha doğal ne olabilir?" ifadesiyle gündelik hayat ile siyaset arasındaki bağlantıyı ortaya koymuştur. Türk kadının siyasi yaşamdan uzak durmasını irdeleyen yazarın ulaştı̆̆ sonuç şudur: Siyasetin çetin bir mücadele ortamı olduğunu gören Türk kadınının, evinin huzurlu ortamını bırakmak istememesidir (Nemluk, 1954a, s. 22).

Melek Erbilen'in 22 Mayıs 1954'te çıkan "Bir Medeniyet Gerçeği" başlıklı köşe yazısında, kadına bakış açısının Doğu ve Batı medeniyetlerini ayıran temel fark olduğu tespiti yapılmıştır. Avrupa'da Hıristiyanlık dininin Meryem'in şahsında kadını merhamet ve şefkatin timsali olarak konumlandırdığını bu yüzden de Avrupa toplumlarında kadına değer verildiğini belirtmiştir. İslamiyetin kabulünden önce Türk kadının, erkeğin saygı gören, eşit hayat arkadaşı olduğunu hatta Tomris Han'ın emrindeki binlerce askerin ondan emir aldığı vurgusunu yapmıştır. Üç kadın tipinden bahseden yazıda ilk olarak sosyal hayattaki etkisini kaybeden kadının zamanla eğlence ve hizmet mahkumu olarak kabul edildiğini belirtmiş̧tir. Bir diğeri özlü Türk anaları olarak tarif edilen bir kadın tipi vardır ki “...Oyah yemenili, temiz başörtülü, üç peşli entarisi el örgüsü bir kuşakla belden sıkılmış, üstübaşı lavanta çiçeği kokan bizim çocukluğumuzun yaşlı kadınları... Fakat bütün o yumuşak havalı kadınlar, Türk ilinde kan dökülmeden temin edilen Meşrutiyeti, İstiklâl harbinin inkılâplarını, hattâ son yılların siyasi istihalelerini hiç sarsıntısız geçmeyi hazırlamış vatan çocukların yetiren özlü Türk analarıdırlar." olarak tanımlamıştır. Son olarak yapılan inkılaplarla birlikte Türk kadının mangal başından iş masasına geçtiği belirtilmiştir. İnkılaplarla oluşan yeni nesil Türk kadınlarının mücadeleci, genç, dinamik ve meslek sahibi oldukları gerektiği ifade edilmiştir. (Erbilen 1954, s. 22).

Tülya Nemluk'ün 29 Mayıs 1954'te çıkan “Kadın Kudreti” başlıklı köşe yazısı, Türk kadınının siyasete karşı ilgisizliği üzerinedir ki Nemluk'un 15 Mayıs'ta çıkan yazısıyla benzer özellik taşımaktadır. Bir önceki yazısında olduğu gibi siyasetin gündelik hayatın içinde olduğunu vurgulamıştır. "...Köyümüze suyu, elektriği getiren veya getirmeyen, delikanlılarımızı Kore'ye gönderen veya oradan geri çağıran, çocuklarımıza iyi veya kötü mektepler veren, elhasıl her gün, her birimizin günlük hayatın tâyin eden şey siyaset değil midir?" ABD kadınlarının siyasetle daha fazla ilgilendiğini, Eisenhower'in Başkan seçilmesinde kadınların rolü olduğunu yazmıştır. Çocuklarla ilgili hak ihlallerinde, dilencilik, gayri meşru çocuklar ve annelerin haklarını en iyi koruyacak olanın kadınlar olduğunu düşünmektedir (Nemluk 1954b, 22). Dergi vadettiği tarafsızlık politikasına uygun olarak 5 Haziran 1954'teki nüshasında, Demokrat Parti milletvekili Nazlı Tlabar'ın, seçim arefesinde İstanbul Radyosunda yapmiş olduğu konuşmaya yer vermiştir (Tlabar, 1954b, s. 21-22).

12 Haziran 1954'te Yazar Perihan Parla "Amerika'da Kadın Kulüpleri” adlı yazısında, Amerikan kadının sosyal yaşamdaki yerine değinirken Türk sosyetesini de söz arasında yermiştir. Amerikalı kadınların ev gezmesinden hoşlanmadıklarını, saatlerini dedikodu yapmaya ayırmadıklarını belirterek Türk kadınına yönelik üstü kapalı bir eleştiride bulunmuştur. Amerikan kadınlarının her mahallede ve semtte bulunan dayanışma kulüplerine üye olduklarını, böylece kendi muhitlerindeki yoksul çocuklara ve dul kadınlara yardımcı olduklarını yazmıştır (Parla, 1954a, s. 24). 
19 Haziran 1954 tarihli "Kadın İnkılabı Ne Vaziyette" başlıklı makale Prof. Dr. Nermin Abadan tarafından yazılmıştır. Abadan'ın yazısının konusu başlığından anlaşılacağı üzere Atatürk devrinde yapılan kadına yönelik inkılapların toplumsalda ne derece benimsendiği ile ilgilidir. Şehir merkezlerinde ve şehirden uzak yerlerde iki farklı uyulamadan söz eden Abadan, Atatürk'ün Türk kadınına verdiği hakların özellikle kırsalda erkek egemenler tarafından kadına tanınmadığını belirtmektedir. Kırsalda köy okullarına devam eden kız öğrenci sayısında yaşanan azalmayı 'elinin hamuruyla erkek işine karışmamayı' kabul eden zihniyetin ürünü olarak tanımlamıştır. Türkiye'nin en az üç bin hemşireye ihtiyacı olmasına rağmen yalnızca dört yüz diplomalı hemşirenin bulunmasını bu zihniyete bağlamıştır. Haremlik-selamlık zihniyetinin kaldırılması için çok çaba gösterilmesini istemiştir. Kadın-erkek eşitliğinin sadece kanunen kâğıt üzerinde kalmayıp toplumsal yaşam içinde de gözle görülür hale gelmesi gerektiğinin altını çizmiştir (Abadan, 1954a, s. 24-25). 26 Haziran'da ise Nermin Abadan'ın yazısını destekler nitelikte Aile kısmında "Kızlarımızı Okutalım" başlığıyla bir yazı kaleme alınmıştır. İlkokullara devam eden kız öğrenci sayısının, erkek öğrenci sayısından \%50 daha az olduğu belirtilmiştir. Nitekim dönemin öğrenci rakamlarına baktığımızda 1950-1951 döneminde 50.262 erkek öğrenci; 17.925 kız öğrenci vardır. 1951-1952 döneminde 55.728 erkek öğrenci; 19.033 kız öğrenci eğitim görmektedir. 1952-1953'te 61.802 erkek öğrenci; 21.163 kız öğrenci bulunmaktadır. 1953-1954 eğitim yılındaysa 68.053 erkek öğrenciye karşın 24.289 kız öğrenci okullarda eğitim görmektedir (Karakök 2011, 96) Yazının devamında kadınların eğitim almadıkları toplumlarda inkılapların kısa ömürlü olacağ1 ve gelişmelerin sonuçsuz kalacağı vurgusu yapılmıştır. O dönem Türk ailelerinin büyük bir kısmının kızların okula gitmesini gereksiz gördüğünü belirten yazıda nesilleri yetiştiren kadınların mutlaka eğitim almaları gerektiği vurgulanmıştır (Abadan, 1954a, s. 20).

Dergide yer alan konulardan biri kadına ve çocuğa yönelik şiddet olaylarıyla ilgilidir. 26 Haziran 1954'te Perihan Parla imzasıyla "İmdat" başlıklı köşe yazının konusu kadına dönük şiddet ve verilen cezaların azlığına dikkat çekilmiştir. Atatürk inkılaplarıyla kadına verilen hakların Türk kadını tarafından kullanılmasını kısıtlayan zihniyetin varlığından bahsetmiştir. Kanunen erkekle eşit haklara sahip olan kadının cehalet ve taassubun kurbanı olduğunu yazmıştır. Küçük çocuklardan, dört çocuk annesine kadar uzanan şiddete/cinayetlere verilen cezaların az olduğunu, önleyici tedbirlerin bir an önce alınması gerektiğini vurgulamıştır (Parla 1954b, 20). Nitekim bu dönemde kadına ve çocuğa yönelik şiddetin varlığını görüyoruz. Örneğin Büyükdere'de altı yaşındaki Meryem adlı kız çocuğuna, Hayri Uyumaz adlı berber çırağı tecavüz ederek öldürmüştür (Milliyet, 1954a, s.1). Bir başka olayda ise bir adam kayınvalidesi, karısı ve baldızını öldürmüştür. Halk ve basın olaya ilgi göstermiştir. Mahkemede suçlunun resimlerini çeken bir foto muhabirine bir kadın saldırmıştır. Gerekçe olaraksa muhabir fotoğrafı çektiği zaman tam suçlunun arkasında olduğunu, gazetede resminin çıkması halinde kıskanç olan kocasının kendisine yapmadığını bırakmayacağını söylemiştir (Milliyet, 1954b, s.3).

3 Temmuz 1954'te Nermin Abadan imzasıyla çıan "Sosyal Hayat ve Amerikan Kadını" başlıklı köşe yazısında $\mathrm{ABD}$ 'deki günlük hayatla ilgili örnekler verilmiştir. NewYork'un sembolü olan heykelin/Özgürlük Anitından hareketle Amerikan toplumunun kadına bakışını anlatmıştır. "...Bu heykel başında defne dalı bulunan muzaffer bir kadını temsil etmektedir. Amerikalıları bu sembol kadar hoşnut edecek daha münasip bir heykel bulunamazdl, çünkü Amerikan idealine göre makbul olan bütün vasıf ve kıymetler kadında, annede, yani cemiyete tahakküm etmeksizin şefkat yolu ile gönülleri teshir eden varlıkta toplanmaktadır." Yazının 
devamında Amerikan kadınının, Amerikan eğitim sisteminin gelişmesinde ve memleketlerinin kültürel kalkınmasında oynadıkları rolden bahsedilmiştir (Abadan, 1954b, s. 22).

10 Temmuz 1954 yılındaki köşe yazısını Türkiye Soroptimist Kulüpleri Sekreteri ve Veznedarı Bedia Çobanoğlu kaleme almıştır. "Soroptimist Kulüpleri Nedir?" başlıklı yazıda ilk olarak soroptimist kelimesinin tanımına yer verilmiştir yani "kadınlar için en iyisi". Soroptimist kulüplerin çalışan kadınlara yönelik davetle üyelik alan kulüpler olduğu belirtilmiştir. Yazının devamında ise soroptimist kulüplerin kuruluş tarihçesi anlatılmıştır: “...ilk soroptimist kulübü 1921 de Kalifornia'nın Okland şehrinde tesis edildi. 1923 de Londra Kulübü, 1924 de Paris Kulübü açıldl... 1928 de Kanada ve Birleşik Devletlerdeki soroptimist kulüpleri bir araya gelerek "Amerika Federasyonu" nu meydana getirmişler, yine ayni tarihte Avrupa kulüpleri de "Avrupa Federasyonu" nu teşkil etmişlerdir...1952'de Kopenhang'da SIA (Soroptimist International Association) adı altında bir dünya sekreterliği kuruldu. (Çobanoğlu, 1954, s. 24)"

Türkiye Kadınlar Birliği, 1925'te Nezihe Muhittin tarafından kurulan, kadınlara yönelik faaliyetleri olan bir dernektir. İlk kuruluş yıllarında mitingler, konferanslar veren birlik, Türk kadınının erkeklerle eşit olması yönünde faaliyetler yürütmüştür. Kadınlara verilen haklarla birlikte 1935 'te dernek dağılmıştır. İkinci kuruluş tarihi ise 1949 'dur ve amacı köy kadınlarının sosyal hayatının seviyesini yükseltebilmektir (Milliyet, 1954e, s. 2). Nitekim Türkiye Kadınlar Birliği Genel Başkanı sıfatıyla Nazlı Tlabar, 24 Temmuz 1954'te "Davamız" başlığıyla kaleme aldığı yazısında da cemiyetin ikinci kuruluş amacının izlerini görmek mümkündür. Türk Kadınlar Birliği, verimli ve sistemli çalışmak için bir anket düzenlemiştir. Birliğe gelen mektuplardan yola çıkılarak Türk Kadınlar Birliğinin çalışma esaslarının şu noktalar üzerinde olması gerektiği sonucu çıkmıştır: İlk olarak inkılapların tam olarak ülkeye yerleşmediği ve bununla ilgili çalışma yapılması istenilmiştir. İkinci olarak Danimarka'daki Kadınlar Birliğinin suni hayat pahalılığına karşı açtığı boykot gibi Türk Kadınlar Birliği de karaborsacılığa, hayat pahalılığına karşı boykot düzenleyerek hükümete destek sağlayabilir. Üçüncü olarak Türk kadının yurt dışında temsil edilmesi için resmi makamlarla işbirliği yapma gerekliliğidir. Sonuç olarak yapılan kamuoyu yoklamaları ile Türk Kadınlar Birliği'nin daha aktif faaliyetlerde bulunması kararı alınmıştır. $\mathrm{Bu}$ derneğin faaliyetleri arasında yaz aylarında kadınlara yönelik voleybol, deniz sporları ve beden eğitimi faaliyetlerinde bulunan kamp açmak vardır (Milliyet 1954c, 2). Birlik, 13 Temmuz 1954'te yeni seçilen idare heyeti eşliğinde İstanbul Valiliğine ziyaretin ardından İstanbul Belediyesine pahalılıkla mücadele, kiracılık gibi konularda işbirliği yapma teklifinde bulunmuştur (Milliyet, 1954d, s. 2).

7 Ağustos 1954'te Perihan Parla imzalı "Yetişkin Eğitimi ve Kadınlarımız" başlıklı makalede yetişkin eğitiminin önemi üzerinde durulmuştur. Bir bireyin şekillenmesinde, topluma faydalı veya zararlı olup olmayacağında, iyi veya kötü terbiye edilmesinde etken rolün kadın olduğu vurgusu yapılmıştır. Kişiliğin oluşma sürecinde ilk terbiyenin, ilk görgünün önemli olduğu noktasına değinen yazar, cahil zümrenin yetişkin eğitimi yoluyla azaltılması gerektiğinin altını çizmiştir. Her şehir, köy ve kasabada kadınlar için çocuk eğitimi, ev ekonomisi, günlük hayata dair pratik bilgileri içeren kültür merkezlerinin açılmasını önermiştir (Parla, 1954c, s. 20).

11 Eylül 1954'te Perihan Parla “Kadına Saygı” başlığıyla bir köşe yazı kaleme almıştır. Gazetelerin tirajlarını arttırmak kadınının bedeninin kullanılması veya karikatürlerde mizah konusu yapılması eleştirilmiştir. Bu tarz resimlerle kadınların rencide edildiği gibi ruh 
hastası ve sapıklara da fırsat verildiği uyarısı yapmıştır. Örnek olaraksa Sarıyer cinayetini vermiştir. Beş yaşındaki bir kız çocuğunu öldüren katil, berberde karıştırdığı bir dergideki çıplak resimlerden tahrik olduğunu söylemiştir. Bu tarz fotoğraflara ve karikatürlere yer verilmesinin ayrıca genç çocukları da etkilediğini eklemiştir. Çıplak kadın fotoğraflarının kullanılmasının Türk terbiyesine de uymadığını ve basındaki diğer kalem arkadaşlarını da bu konuda kendilerini desteklemesini istemiştir (Parla, 1954d, s. 26).

\section{Akis Dergisinde Kadın Sayfasında Yer Alan Kadına Yönelik Haber Metinlerinin Analizi}

Derginin bu bölümlerinde köşe yazılarından farklı olarak kadının kamusal alan dışındaki gündelik yaşam pratikleri ile donatılmış, kadını sıradan öznelere dönüştüren haberlere yer verilmiştir. Gerek dergide kullanılan fotoğraflar gerekse kadına yönelik işlenen konularda ideal kadın vurgusu yapılmıştır. İdeal kadın toplumsal alanda başarılı olmasının yanında modayı takip eden, iyi yemek yapan, güzel bir vücuda sahip, iyi bir eş olarak betimlenmiştir. Kadının bireysel ve toplumsal varlık alanı olan özgürlük anlayışı erkek pratiklere göre şekillenmiştir. Bununla birlikte tüm bu pratikler oluşturulan "Avrupalı Kadınlar" örneğinde tasvir edilmiştir.

15 Mayıs 1954 tarihli nüshasında kadınların vakitlerini ziyan etmelerinden yola çıkarak "Çabuk ve İyi Yaşayalım” yazısı kaleme alınmıştır. Yazıda Türk kadınlarına Avrupa kadını örneğinden hareketle vakitlerini nasıl daha iyi planlamaları gerektiği açıklanmıştır. Bu plana göre "çabuk olup ama acele edilmemeli", "aleyhine tecelli etmediği sürece bol bol süratten yararlanmalı"dır. İki kaidenin uygulanması erkeklerin beklemekten sıkılıp sinirlenmelerini engellemek için önemlidir (Akis, 1954e, s. 21-22).

22 Mayıs 1954 tarihli nüshasında "Fantezi" başlıklı yazıda kullanılan günlük çanta ve çantanın yerleşim düzeninden kadının karakterinin analiz edilebileceğinden bahsedilmiştir. Kadın çantası "Kadınların ruhundaki o ezelî endişenin, lüzumlu şeylerden mahrum kalmak korkusunun, her şeyi muhafaza etmek arzusunun sembolü" olarak tanımlanmıştır. Örneğin çantanın içinde eğer yontulmamış bir kalem, bayram ve yıldönümü tebriklerini yazmak için bir not defteri, atılmamış ilan, not kağıtları varsa ve çantada küçük cisimler gelişi güzel dağılmış şekilde bulunuyorsa bu çantanın sahibi iyi bir kız, emin bir arkadaş, biraz derbeder ancak doğal bir kişidir, denilerek örneklem yapılmıştır (Akis, 1954f, s. 21).

17 Temmuz 1954 tarihli nüshada çalışan kadın, aile, güzellik, koca peşinde konuları ele alınmıştır. "Koca Peşinde" yazısına göre, Lübnan'dan Türk erkekleri ile evlenebilmek için gelen yaşı biraz geçmiş kadınlar anlatılmıştır. Yaşları 28 ile 39 arasında olan bu kadınların İstanbul'a koca bulmak amacıyla geldikleri burada bulamamaları halinde Ankara'ya gittikleri yazılmışırı. Türk erkeklerinin bu durum karşısında tepkisi "Lübnan'dan evlenmek üzere kızların geldiğini duyanlar bunların otellerine akın etmeğe başlamışlardır. Kimisi tombul, kimisi zayıf, kimi sarışın, kimi esmer bir zevce arıyor... Bazlları da teklif mektubu ve resim göndermeğe başlamışlardır. Hanımların dokuzu da bu alâkadan faydalanıp evlenmiş, muratlarına nail olmuşlardır..."olmuştur. "Kadın" bölümünde aile hayatı üzerinde mutfağın önemi üzerine bir bilgilendirme yazısı yazılmıştır. Bu yazıda yeni bir ev inşası sırasında bir evde mutlaka bulunması gereken özellikler üzerinde durulmuştur. Kadınların fonksiyonel bir evde bulunması gereken özellikleri bildiğinden bahisle çizecekleri ev planlarını belediye imar müdürlüklerine sunmasını önerilmiştir (Akis, 1954g, s. 23-24).

SEFAD, 2021; (45): 355-374 
18 Eylül 1954 nüshasında "Kadınlar Arası" sayfasında köşe yazısı bulunmamaktadır. 25 Eylül 1954 nüshasında Kadın sayfasında kadın hayatı, yaşam ve moda hakkında yazılar bulunmaktadır. Çalışan kadınlar "... İş zamanında, dairesinde frapan renkler ve çok fantazi elbiseler giyen, çok mübalâğal bir şekilde boyanan bir kadın, - hakikatte çok dürüst bir insan da olsa- etrafına hiç iyi tesir bırakmaz. Bu tip kadınlar, böyle giyinip süslenmekle, kendilerine iş arkadaşları tarafından haddinden ve lüzumundan fazla, hattâ sululuk derecesinde iltifat edilip kur yapılmasına da tahammüle mecburdur." kılık kıyafet konusunda uyarılmıştır (Akis, 1954h, s. 22)

2 Ekim 1954 nüshasında Kadın sayfasında genç kızlar, portre, güzellik ve moda konuları işlenmiştir. "Genç kızlar" başlıklı yazıda kızların üniversite eğitimi üzerinde durulmuştur. Kızlar arasında üniversiteye gitme oranının artması beraberinde bazı tartışmaları getirmiştir. Bazı aileler kızlarının erkeklerle birlikte okumalarını istememiştir. Yazıda kanunlarımıza göre kadın ve erkeklerin eşit haklara sahip oldukları vurgulanarak kimsenin kadınların yükseköğretime devam edemeyeceğini söyleme hakkına sahip olmadığ1 vurgulanmıştır. Kızların üniversiteye devam etmelerine karşı olan bir grup kızların koca bulmak, yeni erkeklerle tanışmak için üniversiteye gittikleri söylemini gündeme getirmiştir. Yazıda bu söyleme karşı çıkılmış, koskoca bir yükseköğretim eğitiminin tek sebebinin bu olamayacağı belirtilmiştir. Kültürlü bir kadının kocasını her yerde güzel temsil edeceği söylenerek "Devrimizde, sadece güzel yüzlü, taş bebek gibi kadınların modası geçmiştir. İki insan karşı karşıya geldiği, zaman açılan her mevzuda konuşmak ister. Melek kadar güzel de olsa iki kelimeyi bir araya getiremiyen bir kadın artık çekilmez olmuştur. Kadının da okumağa hakkı vardır. O da istediğini yapmak hakkına sahip bir insandır. Artık kimse bütün hürriyetini elde etmiş olan kadının tahsiline mâni olamaz." kadın eğitiminin önemi bir kez daha vurgulanmıştır (Akis, 19541, s. 23).

9 Ekim 1954 nüshasında "Kadın" sayfasında Amerika, aile hayatı ve cemiyet hayatı konu başlıklarına yer verilmiştir. Amerika başlıklı yazıda Amerikan kadınlarının iş yaşamı hakkında örnekler vardır. Amerikan ordusunda önemli mevkilerde 50 bin kadın askerin bulunduğu; ek olarak 250 binden fazla kadın askerin ise Avrupa, Afrika, Uzak Doğu ve Amerika'nın çeşitli yerlerinde vazifeli oldukları bilgisi verilmiştir. Amerikan kadınlarının ev bütçesine katkıda bulunmak, evde oturmaktan hoşlanmamak gibi sebeplerden ötürü çalışma hayatını tercih ettikleri belirtilmiştir (Akis, 1954i, s. 24).

23 Ekim 1954 nüshasında "Kadın" sayfasında güzellik, kütüphanecilik ve kış modası üzerinde durulmuştur. Türkiye'de kütüphaneciliğin gelişimi vse Milli Kütüphanenin kurulması hakkında tarihsel bilgi verilmiştir. "Bilhassa, kadınlarımız için hayli istifade temin edeceği muhakkak. Zira kütüphanecilik, kadına daha fazla yakışan bir meslektir. Kadın elinden çıkmış, bir kütüphane muhakkak ki daha temiz ve muntazam olacaktır."cümlesiyle bu konu üzerinde neden durulduğunu göstermektedir. Kadınlara yeni bir meslek olarak kütüphanecilik önerilmiştir (Akis, 1954j, s. 23).

30 Ekim 1954 nüshasında "Kadın" sayfasında aile, moda, diyet ve portre konularına yer verilmiştir. Portrede Cecilia Pinel Remon incelenmiştir. Panama Cumhurbaşkanı Remon'un eşi olan Cecilia, kadınların haklarını koruyacak bir cemiyet kurmuştur. Kurulan "Yardım Sevenler Derneği" vasıtasıyla halka gıda maddeleri verme, hijyen alışkanlığı kazandırma, okuma ve yazma bilmeyenlere eğitimler verilmiştir. Ayrıca "Sıhhiye Kervanları" adı verilen bir dernek daha kuran Cecilia bu derneğin tüm giderlerini kendisi karşılamıştır. Sıhhiye Kervanları doktorlar, dişçiler, sıhhiye memurlarından oluşmuştur ve ülkenin en ücra köşelerine giderek sağlık hizmeti vermişlerdir (Akis, 1954k, s. 22). 
6 Kasım 1954 nüshasında "Kadın" sayfasında incelenen konular arasında moda, aile ve demokrat çocuk konuları bulunmaktadır. Demokrat çocuk başlığında Amerikan okul sistemi incelenmiştir. Amerikan eğitim sistemindeki demokrasi kavramının anneye, babaya, öğretmene hoş görünmenin çocuklar için gaye olmadığı belirtilmiştir. Çocuğun gayesinin faydalı ve sevilen birey olma gayreti olduğu söylenmiştir (Akis, 19541, s. 21).

13 Kasım 1954 nüshasında "Kadın" sayfasında moda, aile ve sosyal hayat konuları üzerinde durulmuştur. Ailenin ilk şartı olarak 'saadet' görülmüştür. Yazının devamında bir annenin çocuğuna davranışlarına yer verilmiştir. Bir annenin çocuğuna şiddet uygulamasının sonucunda çocuğun iştahsız olarak tepki verebileceğine dikkat çekilmiştir. “Kocanızla sık sık münakaşa ediyordunuz. Kaynananızla aranızda daimi bir gerginlik ve soğukluk vardı. Herhangi bir sebepten neşeli değildiniz. İşte bütün bu bebekliğinde çocuğun hassas ruhuna bombardıman tesiri yapan huzursuzluklar büyüklerden öç almak arzusunu yaratır, en fenası, bilhassa hilkaten asabi çocuklarda yaşamaya karşı bir isteksizlik ve dolayısıyla «intiharla müdafaa» denilen hali ortaya çıkarır" diyerek aile mutluluğunun çocuk üzerindeki etkisini gözler önüne sermiştir (Akis, 1954m, s. 20-21).

20 Kasım 1954 nüshasında "Kadın" sayfasında köşe yazısı bulunmamakla birlikte cemiyet haberlerinde Amerikan Kız Kolejinin yemeğine yer verilmiştir. Bir başka üzerinde durulan konu ise rejimdir. Fazla kilosunu vermek isteyen kişiler için örnek bir menü paylaşılmıştır: "Mütehassıslar şehirde yaşıyan bir insan için normal olarak aşă̆ı yukarı günde 2.700 kalori hakkı tanıyor. Bunun 1.775 kalorisi ekmek, yă̆ ve kahvaltı gıdalarını ihtiva ediyor. Meselâ: 250 gr. süt - 235 kalori. 45 gr. yă̆ (herhangi çeşit) -400 kalori. 250 gr. ekmek - 600 kalori. 40 gr. şeker - 440 kalori 10 gr. çukulata - 50 kalori. Yekûn: 1.775 kalori. Demek ki 2.700 kaloriden geri kalan 925 kalorilik gıdayı öğle ve akşam yemeklerine bölmek icap edecek. Meselâ bir öğle yemeği: Havuç rendesi 70 gr. - 30 kalori Biftek 100 gr. - 165» Kızarmış patates 200 gr. - 180 Yoğurt 100 gr. - 65» 2 Mandaline 100 gr. - 45» Yekûn: 485 kalori Bir akşam yemeği: Tavuklu, sebzeli çorba 250 gr. - 190 kalori Tavuk parçası 45 gr. - 72» Salata, pancar veya yeşillik 60 gr. - 20» 1 pasta 50 gr. - 125» Portakal 100 gr. - 50» Yekûn: 457 kalori” Bu örnek menüyle rejim yapanlara dikkat etmeleri gereken noktalar hatırlatılmıştır (Akis, 1954n, s. 22).

27 Kasım 1954 nüshasında "Kadın” sayfasında moda, sosyal hayat konuları üzerinde durulmuştur. Sosyal hayat kısmında okul çıkışında kız öğrencilerin peşine takılan genç erkek öğrenciler üzerinedir. "Aman, orta mektep ve lise çă̆ında olan genç kızlar ve delikanlılar en kritik yaşlardadır, bir arada bulunmaları akıllarım fena yollara çeler, onları bir sırada dirsek dirseğe oturtmıyalım, tecrid edelim, ayrı ayrı daha iyi okurlar zihniyeti ile kız ve erkek mektepleri birbirinden ayrılmıştır; halbuki, mektep dışında, her yasak şeyin yaptı̆̆ı tepki gibi bir araya gelmeğge çalışırlar, daha da fazla zaman kaybederler, dikkatleri de dağılır." diyerek kız ve erkeklerin bir arada eğitim görmelerinin bu tarz davranışları ortadan kaldıracağı düşüncesi belirtilmiştir (Akis, 1954o, s. 25-26).

4 Aralık 1954 nüshasında “Kadın” sayfasında köşe yazısı bulunmamaktadır. Bu nüshada cemiyet, moda ve çocuk terbiyesi konuları üzerinde durulmuştur. Cemiyet haberleri kısmında Türk Kadınlar Birliği'nin faaliyet göstereceği alanlardan bahsedilmiştir. $\mathrm{Bu}$ alanlar içinde Türk filmlerinin seviyesinin yükseltilmesi, muzır neşriyata izin verilmemesi, yerli malını kullanmaya teşvik etmek, köy ve şehir kadını arasındaki yaşam farkı uçurumunu kapatmak vardır. Moda kısmında şıklık konusu üzerinde durulmuştur. Çocuk terbiyesi konusunda ise annelere çok sinirli olmamaları tavsiye edilmiştir (Akis, 19540̈, s. 22-24). İncelenen konular arasında aile, moda, sosyal hayat ve çarşı vardır. Çarşı 
kısmında et seçiminde dikkat edilmesi gereken hususlara yer verilmiştir. Et alırken rengine, dokusuna dikkat edilmesi gerektiğinin altı çizilmiştir. Sosyal hayat kısmında fazla kilonun verilmesi için mutlaka spor yapılması gerekliliğinden bahsedilmiştir. Moda kısmındaysa kısa saç modası üzerinde durulmuştur. Yalnız "1920'nin "rüzgârla dă̆̆lmış" modasının yalan akrabası sayılabilecek bu günün kırpık modası kadınların yeniden haşarılığı ellerine alacaklarının vahim bir işaret" cümlesiyle bu modanın yazıyı yazan tarafından pek de hoşa gitmediği anlaşılmaktadır (Akis, 1954p, s. 18-21).

18 Aralık 1954 nüshasında ise yine moda üzerinde durulmuştur. Bu sayfada ek olarak çorap reklamına yer verilmiştir." Hayatı Bir Tele Bağlı, Tel Koparsa Felaket" başlığı altındaki reklamda ip üzerinde yürüyen bir balerin kadın kullanılmıştır (Akis, 1954r, s. 24). Bu nüshada köşe yazısı bulunmamaktadır.

25 Aralık 1954 nüshasının inceleme konusu mayo modasıdır. Ayrıca bir kadının gardropunda bulunması gereken parçalara yer verilmiş̧ir. En az üç ayakkabının dolapta bulunmasını, ayakkabıların ömrünü uzatması bakımından elzem olarak görülmüştür. Dansa gitmek için iki ipekli döpiyes, bir yünlü döpiyes, iki eteklik, üç bluz, korse, gecelik olmazsa olmaz olarak kabul edilmiştir. Dikkat çekici bir öneri ise dolapta altı kilot olması ve bunlardan iki tanesinin mutlaka siyah olmasıdır (Akis, 1954s, s. 20).

\section{SONUÇ}

Araştırmada incelenen derginin kadın köşesinin, 15 Mayıs -17 Temmuz 1954'te "Kadınlar Arasında"; 24 Temmuz-21 Ağustos 1954'te "Kadınlar Aleminde" ve 28 Ağustos 1954 itibariyle "Kadın" adıyla yayınlandığı tespit edilmiştir.

Dergi ve gazeteler toplumda yaşanan ekonomik, siyasal ve kültürel değişimlerden etkilenen ve o dönemin dinamizmini yansıtan bir yapı ile şekillenirler. Akis dergisi kadın dergisi olmamakla birlikte "Kadınlar Arasında" bölümü ile yayımlandığı dönemde kadının toplumsal konumu hakkında bilgiler vermiş, yayınlanan köşe yazıları ve haber metinleri ile ideal Türk kadını imajını yansıtmıştır. Özellikle kadınlaın eğitimi, toplumsal ve siyasal alana yönelik katılımları, kadın haklarının kabulü ve yaygınlaştırılması noktasında örgütlü faaliyetlerde bulunmaları ve kadın-erkek eşitliğinin tüm alanlarda varolması gerekliliği derginin ilgi duyduğu konuların başında gelmektedir. Dergide Atatürk inkılapları ile kadına verilen değere vurgu yapılmıştır. Ancak inkılapların kırsal-kentsel alanda yaşayan kadınlar arasında uygulanması ve yaygınlaşması konusunda farklılıkların olduğu belirtilmiştir. Kırsal alanda var olan geleneksel toplumsal yapının kadınların kendilerine verilen hakları kullanması konusunda kısıtlamalar meydana getirmesi eleştirilmiştir. Özellikle köşe yazılarında Atatürk inkılaplarının ülkeye tam olarak yerleşmesi ve uygulanabilmesi noktasında kadınların örgütsel bir yapı içerisinde birleşip mücade sürecine katılmaları desteklenmiştir.

Dergide kadın-erkek eşitliği konusuna değinilmesi, kadına yönelik şiddet/cinayet haberlerinin ele alınması ve buna yönelik verilen cezaların tartışılması Akis'in kadın sorunlarının kamuoyunda görünür olmasını destekleyici bir işleve sahip olduğunu göstermektedir. Dergide hem köşe yazılarında hem de haber metinlerinde dikkat çeken başka bir nokta ise; oluşturulmak istenen İdeal Türk Kadını algısında Amerikan kadınlarının rol model olarak alınmasıdır. Ancak burada bahsedilen konu, Amerikan kadınlarının sadece siyasete yönelik ilgisi, aile ekonomisine katkıları ve sosyal yardımlaşma sürecindeki konumları rol model olarak sunulmasıdır. 
Dergide kadın algısı geleneksel, popüler yaşam ve Cumhuriyetin kadına verdiği haklar ekseninde şekillendiği görülmektedir. Bunun yanı sıra derginin kadın bölümünde özellikle yükseköğretim ile ilgili kısımda geleneksel yapıdan kopmadığı gözlenmiştir. Şöyle ki: bir kadının eğitimli ve meslek sahibi olmasının evleneceği erkeği yükselteceği vurgusuyla toplumsal cinsiyet meşrulaştırmasının yapıldığı da gözden kaçmamaktadır.

Sonuç olarak Akis dergisi, yayımlandığı dönemde "Kadınlar Arasında" bölümüyle kadınların siyasal, toplumsal ve kültürel alandaki mücadelesine önem vermiştir. Mücadeleyi destekleyici yazılarla okuyucu kitlesini bilgilendirme ve aydınlatma konusunu ilke edinmiş, modernleşme sürecinde İdeal Türk Kadını algısının yaratılması konusunda rol oynamıştır.

\section{SUMMARY}

Magazines and newspapers are shaped by a structure that is affected by the economic, political and cultural changes in the society and reflects the dynamism of that period. However, women, who were removed from the position of producers in most women's magazines, are depicted in a lifestyle built by social prejudices. Magazines for women do not focus on women against concepts such as social problems, justice, equality, and poverty; It has been reduced to a position symbolized by concepts such as love, money and beauty.

Although Akis magazine is not a women's magazine, it provided information about the social position of women in the period it was published with the section "Among Women", and reflected the image of the ideal Turkish woman with its published columns and news articles.

Akis, which has an important place in the political magazine understanding of the period, included the issue of women being in the public sphere in the section prepared for women, in columns and news texts. Some numbers cited in Turkey and in the world, photographs of women in their productive areas used in the magazine cover.

The aim of the study is to determine the perspective and positioning of a weekly magazine with a political identity towards women. In the study, qualitative content analysis method was used in accordance with the purpose of the research. 33 copies of Akis journal published between 1954-1967 were included in the scope of the research. The "Among Women" section in the magazine has been analyzed in two categories. In the first category, columns prepared for women; women-politics, woman-social position, woman-education, positioning in the search for women's-rights are taken into account. In the second category, the traditional role of women in news texts for women was examined in terms of daily life practices. Since the column articles and news texts for women in the journal copies included in the study are repetitions of each other, the study was limited to the number of journals that touch on different topics. In this direction, 10 columns in the copies prepared for women between 15 May and 11 September 1954 and 15 current articles / news in copies between 15 May and 25 December 1954 were discussed.

As a result, Akis magazine focuses on issues such as women's education, social and political activities, women's rights, organizational struggles and gender equality. The magazine emphasized the value given to women with Atatürk's reforms. However, it has been stated that there are differences in the implementation and spread of reforms among women living in rural-urban areas. It has been criticized that the traditional social structure in rural areas creates restrictions on women in exercising their rights. Especially in the

SEFAD, 2021; (45): 355-374 
columns, women were encouraged to unite in an organizational structure and participate in the struggle for the full settlement and implementation of Atatürk reforms in the country.

Mentioning the issue of equality between women and men in the magazine, discussing the news of violence / murder against women and discussing the penalties imposed on it show that Akis has a function that supports the visibility of women's problems in the public. Another point that draws attention both in columns and news articles in the magazine; It is to take American women as role models in the perception of the Ideal Turkish Woman. However, the issue mentioned here is that American women are only presented as a role model for their interest in politics, their contribution to the family economy and their position in the social assistance process.

In the magazine, it is seen that the perception of women is shaped on the axis of traditional, popular life and the rights given to women by the Republic. In addition, it was observed that the magazine did not break with the traditional structure in the women's section, especially in the section related to higher education. That is to say: It is not overlooked that gender legitimization is made with the emphasis that a woman's education and profession will raise the man she will marry.

As a result, Akis magazine emphasized the struggle of women in the political, social and cultural spheres with its "Among Women" section at the time of its publication. It adopted the principle of informing and enlightening the readership with articles supporting the struggle, and played a role in creating the perception of the Ideal Turkish Woman in the modernization process. 
Makale Bilgileri

Etik Kurul Karart:

Katılımo Rizası:

Etik Kurul Kararından muaftır.

Mali Destek:

Katılımc1 Yok

Çalışma için herhangi bir kurum ve projeden mali destek alınmamıştır.

Çıkar Çatışması:

Çalışmada kişiler ve kurumlar arası çıkar çatışması bulunmamaktadır.

Telif Hakları:

Telif hakkına sebep olacak bir materyal kullanılmamıştır.

Article Information

Ethics Committee Approval: Informed Consent:

Financial Support:

Conflict of Interest:

Copyrights:
Exempt from the Ethics Committee Decision.

No participant

No financial support from any institution or project.

No conflict of interest.

No material subject to copyright is included. 


\section{KAYNAKÇA}

Abadan, N. (1954). Kadın inkılabı ne vaziyette. Akis, 19 Haziran 1954.

Abadan, N. (1954). Sosyal hayat ve Amerikan kadını. Akis, 3 Temmuz 1954.

Akis (1954a, 15 Mayıs). Kendi aramızda. Erişim adresi: http://www.inonuvakfi.com/akis/1954_01.pdf.

Akis (1954b. 18 Eylül). Kendi aramızda. Erişim adresi: http://www.inonuvakfi.com/akis/1954_19.pdf.

Akis (1954c, 22 Mayıs). Kendi aramızda. Erişim adresi: http://www.inonuvakfi.com/akis/1954_02.pdf.

Akis (1954d, 26 Haziran). Kendi aramızda. Erişim adresi: http://www.inonuvakfi.com/akis/1954_07.pdf.

Akis (1954e, 15 Mayıs). Çabuk ve iyi yaşayalım. Erişim adresi: http://www.inonuvakfi.com/akis/1954_01.pdf.

Akis (1954f, 22 May1s). Fantezi. Akis, Erişim adresi: http://www.inonuvakfi.com/akis/1954_02.pdf.

Akis (1954g, 17 Temmuz). Koca peşinde. Erişim adresi: http://www.inonuvakfi.com/akis/1954_10.pdf.

Akis (1954h, 25 Eylül). Kadın hayatı, kadın mı erkek Mi?. Erişim adresi: http://www.inonuvakfi.com/akis/1954_20.pdf.

Akis (19541, 2 Ekim). Genç kızların üniversiteye rağbeti artıyor. Erişim adresi: http://www.inonuvakfi.com/akis/1954_21.pdf.

Akis (1954i, 9 Ekim). Amerikan erkeği ve kadınları 1' e 3 mü? Erişim adresi:

Akis (1954j, 23 Ekim). Kütüphanecilik yeni bir enstitü. Erişim adresi: http://www.inonuvakfi.com/akis/1954_24.pdf.

Akis (1954k, 30 Ekim). Portre, Panama'nın 1 numaralı kadını. Erişim adresi: http://www.inonuvakfi.com/akis/1954_25.pdf.

Akis (1954l, 6 Kasım). Demokrat çocuk. Erişim adresi: http://www.inonuvakfi.com/akis/1954_26.pdf.

Akis (1954m, 13 Kasım). Aile saadeti. Erişim adresi: http://www.inonuvakfi.com/akis/1954_27.pdf.

Akis (1954n, 20 Kasım). Rejim. Erişim adresi: http://www.inonuvakfi.com/akis/1954_28.pdf.

Akis (1954o, 27 Kasım). Sosyal hayat. Erişim adresi: http://www.inonuvakfi.com/akis/1954_30.pdf.

Akis (1954ö. 4 Aralık). Cemiyet hayatı. Erişim adresi: http://www.inonuvakfi.com/akis/1954_31.pdf.

Akis (1954p, 11 Aralık). Kısa saç moda. Erişim adresi: http://www.inonuvakfi.com/akis/1954_32.pdf. 
Akis (1954r, 18 Aralık). Süper bale. Erişim adresi:

http://www.inonuvakfi.com/akis/1954_33.pdf.

Akis (1954s, 25 Aralık). Moda. Erişim adresi: http://www.inonuvakfi.com/akis/1954_34.pdf.

Aydın, H. (2009). Kadın (1908-1909): Selanik'te yayınlanan ilk kadın dergisi üzerine bir inceleme. Selçuk Üniversitesi Sosyal Bilimler Enstitüsü Dergisi, 22, 147-156.

Aydın, H. (2015). Meşrutiyet'ten Cumhuriyet'e Türkiye'de kadın. Current Research in Social Sciences, 3 (1), 84-96.

Çakır, S. (1996). Osmanlı Kadın Hareketi. İstanbul: Metis Yayınları.

Çakır, S. (2009). Nermin Abadan-Unat: Türkiye'de politik iklim, siyaset bilimi alanında angaje olmayan çalışmaları neredeyse imkansız kılıyor. İstanbul Üniversitesi Siyasal Bilgiler Fakültesi Dergisi, 40, 31-41.

Çobanoğlu, B. (1945). Soroptimist kulüpleri nedir?. Akis, 10 Temmuz 1954.

Erbilen, M. (1954). Bir medeniyet gerçeği. Akis, 22 Mayıs 1954.

Gökçimen, S. (2008). Ülkemizde kadınların siyasal hayata katılım mücadelesi. Yasama Dergisi, 10, 5-59.

http://www.inonuvakfi.com/akis/1954_22.pdf.

https://m.bianet.org/bianet/kadin/43145-on-maddede-turkiyede-kadin-hareketi.

Karabulut, S. (2011). 1950'lerde kadının sosyalleşmesinde basının önemi: kadın gazetesi örneği. Belgi Dergisi, 1(1), 87-97.

Karakök, S. (2011). Menderes Dönemi'nde (1950-1960) Türkiye'de eğitim. Yükseköğretim ve Bilim Dergisi, 1(2), 89-98.

Kılıç, N. (2015). Osmanlı kadın dergilerine bir örnek: Mürüvvet. Itobiad: Journal of the Human $\mathcal{E}$ Social Science Researches, 4(3), 744-769.

Koçer, D. (2009). Demokrat Parti dönemi (1950-1960) kadın dergilerinde kadın imaj1. Zeitschrift für die Welt der Türken/Journal of World of Turks. 1(2), 131-143.

Malkoç, S. ve Yılmaz-Vefikuluçay, D. (2019). Cumhuriyet dönemi kadın dergileri (19231992). OPUS Uluslararası Toplum Araştırmaları Dergisi, 10(17), 2139-2156.

Milliyet (1954a, 15 Mart). İğrenç bir cinayet. Erişim adresi: http://gazetearsivi.milliyet.com.tr/Arsiv/1954/03/15.

Milliyet (1954c, 10 Temmuz). Kadınlar Birliği Kampı. Erişim adresi: http://gazetearsivi.milliyet.com.tr/Arsiv/1954/07/10.

Milliyet (1954d, 13 Temmuz). Kadınlar birliği belediyeden vazife istedi. Erişim adresi: http://gazetearsivi.milliyet.com.tr/Arsiv/1954/07/13.

Milliyet (1954e, 3 Ağustos). İstanbul kadınlar birliğinin verimli ve tesirli çalışmaları. Erişim adresi: http://gazetearsivi.milliyet.com.tr/Arsiv/1954/08/3.

Milliyet, (1954b, 12 Haziran). Kadıköy cinayetinin faili dün mahkemede bayıldı. Erişim adresi: http://gazetearsivi.milliyet.com.tr/Arsiv/1954/06/12

SEFAD, 2021; (45): 355-374 
Mutlu, N. (2009). Popüler kadın dergilerinde kadın (Basılmamış Yüksek Lisans Tezi). Selçuk Üniversitesi, Konya.

Nemluk, T. (1954). Kadın kudreti. Akis, 29 Mayıs 1954.

Nemluk, T. (1954). Türk kadını ve siyaset. Akis, 15 Mayıs 1954.

Parla, P. (1954). Amerika' da Kadın Kulüpleri. 12 Haziran 1954.

Parla, P. (1954). İmdat. Akis, 26 Haziran 1954.

Parla, P. (1954). Kadına Saygı. Akis, 11 Eylül 1954.

Parla, P. (1954). Yetişkin eğitimi ve kadınlarımız. Akis, 7 Ağustos 1954.

Tekeli, Ş. (2017). On maddede türkiye'de kadın hareketi. Erişim tarihi:

Tekelioğlu, İ. (2016). İslam öncesi Türk toplumunda kadının konumu üzerine. A. Ü. Türkiyat Araştırmaları Enstitüsü Dergisi, 55, 209-224.

Tlabar, N. (1955). Davamız. Akis, 24 Temmuz 1954.

Yıldırım, B. ve Seyhan, S. (2015). 1914 yılında yayınlanan kadın gazetelerinden 'kadınlık'a göre kadın. Galatasaray Üniversitesi İletişim Dergisi, 23, 39-65.

Yılmaz, E. (2010). 1954 Seçimlerinin önemi, öne çıkan özellikleri ve siyasi sonuçları. EJournal of New World Sciences Academy Humanities, 5(4), 541-551. 